\title{
Community work programmes as job creation mechanism: A case of Tshwane Metropolitan municipality
}

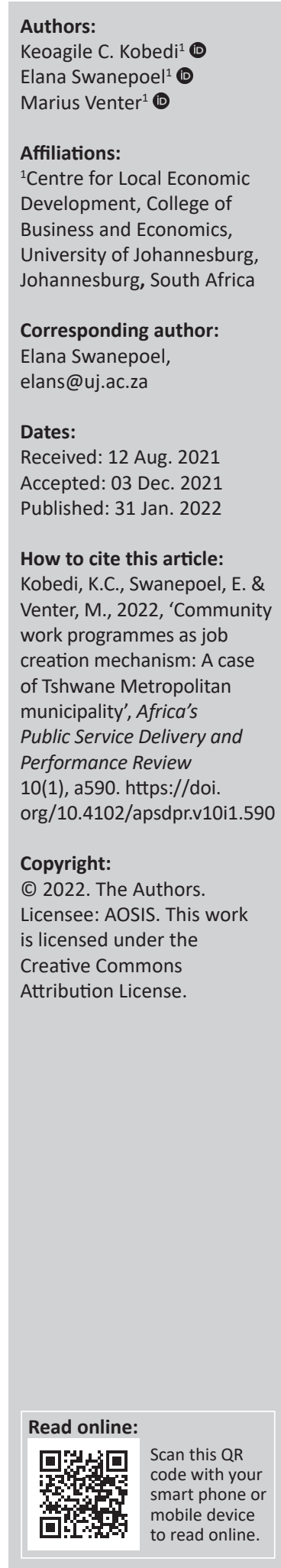

Background: To address poverty and unemployment, local government implemented programmes, such as the Community Work Programme (CWP), aimed at empowering the community through the provision of employment and skills to provide a safety net to the poor by allowing them to earn a monthly wage.

Aim: This study aimed to investigate the CWP's contribution towards employment or job creation within Region 1 of the Tshwane Metropolitan Municipality community, specifically in Erasmus and Soshanguve.

Setting: A CWP was started 11 years ago in the City of Tshwane, in Region 1 - Erasmus and Soshanguve. It provides wages to 2000 people.

Method: A cross-sectional quantitative survey was conducted using a structured questionnaire with a face-to-face interview of 219 respondents.

Results: The results reveal that the CWP is contributing financially to the well-being of the participants, but the latter tend to stay with the CWP and do not progress to permanent employment. Although some participants intend to start their own business, it seems they lack the skills.

Conclusion: Although participants benefited financially and socially, it seems that limited skills were acquired, particular entrepreneurial skills relevant to starting an own business venture. It is recommended that the data be further analysed with regard to the level of satisfaction and skills capacity development by the CWP.

Keywords: community work programme; job creation; local economic development; municipality; community empowerment; skills development; Tshwane municipality; satisfaction level; entrepreneurial skills.

\section{Introduction}

In 2000, the South African government signed the Millennium Development Goals declaration (MDGs) to eradicate extreme hunger and poverty by 2015 (South African Local Government Association [SALGA] 2016:16), but by 2021, little progress had been made as far as economic development is concerned. By 2021, the unemployment rate had increased to $32.6 \%$, with 7.2 million unemployed (Statistics South Africa [Stats SA] 2021:1). The South African government has used various strategies, including progressive fiscal redistribution, to address unemployment, poverty and inequality (Cook 2019:7). One of government's strategies is the advancement of local economic development (LED) to ensure economic inclusion at the local level. Local economic development is referred to as a bottom-up approach to development, where local government is influential in enhancing business opportunities, increasing employment and upgrading communities using natural and human resources (Kahika \& Karyeija 2017:2; Rogerson 2014:205).

At a local sphere, the Tshwane Metropolitan Municipality is faced with poverty and unemployment. In 2017, the unemployment rate was $24 \%$ in the City of Tshwane, whilst $50 \%$ of the population lived below the minimum poverty level (City of Tshwane 2019:11). Approximately 811570 households (27.7\% of the Tshwane municipal population) reside in Region 1, representing the highest number of residents living in poverty (City of Tshwane 2019). Region 1, located at north of the city, includes townships such as Erasmus, Soshanguve, Mabopane, Ga-Rankuwa, Winterveld and Pretoria North. According to the 2011 census, 127000 economically active individuals in this region were unemployed, representing 19\% of the region's population (City of Tshwane 2019). 
To address poverty and unemployment, various programmes were implemented at the local government sphere, such as the Expanded Public Works Programme (EPWP) and Community Work Programme (CWP). The EPWP was first implemented in 2003 to enhance skills development and provide temporary employment (Department of Corporate Governance and Traditional Affairs [CoGTA] 2019c). Although the EPWP provided more than a million temporary jobs in a period of 5 years, unemployment remained a challenge in South Africa (CoGTA 2019c). The CWP, an offshoot of the EPWP, was first implemented in 2007 by the Department of Public Works to support the EPWP. Both these programmes aimed at empowering the community through the provision of employment and skills as a safety net to the poor enabling them to earn a monthly wage (CoGTA 2019b:5).

The CWP offers part-time work for the local unemployed. The CWP participants work $8 \mathrm{~h}, 2$ days a week, at a rate of R97.50 a day (CWP Manager, 2021, personal conversation). Starting as a pilot programme in 2007, the CWP has expanded from 45 municipalities in 2011 to 196 municipalities in 2016 in Gauteng, Limpopo, KwaZulu-Natal and Mpumalanga (CoGTA 2016:10). During the 2018-2019 financial year, an estimated 280000 participants benefitted from this programme (CoGTA 2019a:8). In Region 1 of the Tshwane Metropolitan Municipality, the number of CWP participants increased from 500 in 2009 to 2000 in 2016 in Erasmus and Soshanguve (CoGTA 2016). Community Work Programme participants within the Tshwane Metropolitan Municipality contribute to the development of their community by assisting with the following community services: food security and security support; mentorship; support to Early Childhood Development Centres; support to schools; community safety; home-based care and auxiliary care services and environmental programmes.

The CWP provides opportunities for the unemployed to gain valuable skills, such as agricultural skills and work exposure (Andersson \& Alexander 2016:173). The CWP improves the lives of individuals and the communities in which they live (CoGTA 2016:10; Mullagee \& Bruce 2015:33).

Previous research has mainly focused on the macro- and micro-economic impact of EPWP. Altman and Hemson (2007:20) examined the role of the EPWP in creating employment and found that although the programme only provides temporary employment opportunities, the unemployment rate would be worse in the absence of such programmes. Baur and Venter (2019:6) focused on the LED strategy in the arts and culture sector of the EPWP and found that the sector plays a crucial role by enhancing innovation and providing job opportunities, which led to an improved environment for sustainable economic development. Mabusela (2019:119) studied the lived experiences of EPWP trainees and found that such programmes are regarded as a social safety net rather than a labour market contribution. Assessing the CWP's impact on violence in Orange Farm,
Langa (2015:43) concluded that the CWP contributed to crime reduction in Orange Farm, as the programme facilitated social relations and strengthened social bonds within the surrounding communities. Moreover, Puwana (2015:20) found that although the CWP implementation in Grabouw has been challenging, the communities are more united than before.

Although Moeti's (2013) research focused on the City of Tshwane, he investigated the implementation of the EPWP within the city with a view to understand the current implementation approach. It seems that no prior research has focused on the CWP's contribution towards job creation within Region 1 of the Tshwane Metropolitan Municipality community.

\section{Literature review}

This section contextualises LED, the CWP and job creation.

\section{Local economic development}

Local economic development was introduced in the White Paper on Local Government of 1998 (CoGTA 1998) as a strategy for developing local economies and it is defined as:

Local government committed to working with citizens and groups within the community to find sustainable ways to meet their social, economic and material needs, and improve the quality of their lives. (p. 18)

It is supported by the South African Constitution (section 152 [c] and 153 [a]), which stipulates that local government must promote social and economic development within communities. According to Venter (2014:722), LED transpires when a community decides to advance the economy of the society by working together with various stakeholders to ensure decent jobs are created and living conditions are improved. Thus, the role of local government in reducing poverty and creating jobs depends on collaboration amongst all economic structures to identify resources and ensure that the local economy is investor-friendly, fully functional and competitively productive (Mashinini 2018:19; Rogerson 2010:483). Meyer (2014:624) stressed that the desired LED outcomes are reduced poverty and job creation.

Several policies and acts contributed to the establishment of LED. The local government: Municipal System Act 32 of 2000 was the first act to support LED (Republic of South Africa 2000:2), followed by the New Growth Path (NGP), which was aimed at providing job opportunities in all spheres of the country (Department of Economic Development 2011:2). The National Development Plan (NDP) built on the NGP to generate new ways of creating jobs within the country (National Planning Commission 2013:14). In 2006, the first National Framework for LED (NFLED) 2006-2011 was implemented (CoGTA 2020:4). Building on the lessons learnt, the revised NFLED 2018-2028 focuses on improving the performance and recognition of LED within the country (CoGTA 2018:14). 
The main objective of the NFLED 2018-2028 is to provide strategic direction to actors, LED agents and their activities to achieve competitive, innovative, sustainable, inclusive local economies that maximise local opportunities, contribute to national and provincial development objectives and address local needs (CoGTA 2018:14). The NFLED has six core pillars that influence the development, design and implementation of LED (CoGTA 2018:15). Although all these pillars aim to develop local economies, Pillars 2 and 3 focus more on developing local economies through the provision of skills training and job opportunities to the poor (CoGTA 2018:15). To support the NFLED, the government implemented the CWP, aimed at developing the poorest communities by building participants' employment skills (Bruce 2015:26).

\section{Public works programmes in South Africa}

Public works programmes (PWPs) are defined as:

[A]ll activities which entail the payment of a wage (in cash or in kind) by the state, or by an agent acting on behalf of the state, in return for the provision of labour, in order to i) enhance employment and ii) produce an asset (either physical or social), with the overall objective of promoting social protection for participants. (Govender, Sithebe \& Raiman 2019:2)

Public works programmes are considered to be 'public actions taken in response to levels of vulnerability, risk and deprivation which are deemed socially unacceptable within a given polity or society' (Conway, De Haan \& Norton 2000:2). In 1994, the PWPs were renamed the National Public Works Programmes (NPWPs) to follow the mandate of the Reconstruction and Development Programme (RDP) in developing the infrastructure, creating labour-intensive job opportunities and providing capacity building and skills development (Mogagabe 2016:10). In 2005, the first PWP, the EPWP was established with the objective to empower unskilled residents by providing short- to medium-term employment to eradicate poverty (Moeti 2013:1). In 2007, the CWP, a municipal-based programme, was implemented to improve the poorest communities and supplement existing government strategies, such as the EPWP, without displacing or disrupting them (Philip 2013:9).

According to Meth (2011:7), the EPWPs or PWPs cannot address the unemployment problem, as the job opportunities created by these programmes are insignificant when compared with the unemployment crisis. In addition, the design of the projects is constrained by national budget.

However, Mogagabe (2016:90) disagreed and argued that PWPs are effective government strategies to alleviate unemployment. With reference to the EPWPs in Mabopane, the author concluded that participants were better off after such programmes, as they had gained skills and training in agriculture. This enabled them to start their own gardens and open vegetable stalls after exiting the programme.

The key objective of the four types of PWPs (McCord 2008:2) is the provision of employment at a prescribed wage for those who are unable to find alternative employment, as a form of social safety net (McCord 2013:1). Del Nnino, Subbarao and Milazzo (2009:2) emphasised that although PWPs are substantial safety net instruments used in various situations, most programmes are not sustainable; except for the employment guarantee scheme.

TheEPWP is implemented in four sectors, namely infrastructure, social, environmental and culture and 'non-state' (promoting employment throughnon-profitorganisations). The participants are provided with 100 days of work per annum. In its second phase, between 2009 and 2014, an estimated 1 million temporary jobs were funded by the EPWP (McCord 2017:155).

During Phase 3, approximately 1 million jobs were provided each year for a period of 5 years, from 2014 to 2019. Although individuals are permitted to participate in various projects, there is no evidence that the programme has led to permanent job opportunities (CoGTA 2019c:19).

Meth (2011:43) argued that the EPWP offers temporary employment relief and should be treated as such; by so doing, its success will be well recognised. McCord (2005:579) added that the success of the EPWP is limited, as it primarily demands low-skill labour. Several factors may contribute negatively towards the success of the programme:

$[L]$ ack of potential to accumulate the productive assets required to stimulate secondary labour market activity; training which is not perceived as valuable by recipients; and failure to recognise the heterogeneity of the unemployed. (McCord 2005:579)

Although the EPWP has been successful in terms of providing training in life coaching, auxiliary services, mentorship, computer and report writing skills, it could not provide participants with permanent jobs (Parenzee \& Budlender 2016:4). However, some EPWP participants received internships and learnerships within the programme, as well as training in basic HIV and AIDS courses, web-based system training, integrated reporting systems, project management and management information system training (MkhatshwaNgwenya 2016:181). From a qualitative study interviewing 25 participants, Zulu, Nyawo and Mashau (2017) concluded that the EPWP Zibambele project has not effectively developed and capacitated the individuals with other critical skills. Although Mogagabe (2016:10) and Baur and Venter (2019:6) presented EPWPs as a solution for unemployment in South Africa, Meth (2011:43) asserted that too much is expected from such programmes, as EPWPs aim to provide temporary jobs within the economy.

\section{Community work programme}

Although the CWP is a national government programme, it is implemented in local communities with the assistance of non-profit agencies and mayoral committees, which have experience in participatory community development strategies and understand the needs of the communities (Philip 2013:14). As the CWP intends to strengthen poor communities by promoting social and economic inclusion 
(CoGTA 2015:3), it creates job opportunities and allows the poorest to earn a monthly wage.

The CWP differs from any other PWP in three respects. Firstly, to large numbers of people (a minimum of 1000 at a site), it offers 2 days of work every week indefinitely to those who are unemployed or under-employed, ensuring predictable and regular work. Secondly, it uses 'public employment as a catalyst for community development' (Andersson \& Alexander 2016:157). Thirdly, work activities depend on whatever the local community decides is 'useful work'; the work thus contributes to a popularly defined public good (Andersson \& Alexander 2016:157).

In 2007, the CWP was instituted as an offshoot and in support of the EPWP. The CWP is a community-based programme implemented to fight structural unemployment and provide social protection in South Africa (Philip 2013:6). According to Langa and Von Holdt (2011:259), the CWP's implementation in South Africa was inspired by the National Rural Employment Guarantee Act in India. The CWP is a constitutional strategy that provides decent short- to medium-term work opportunities at a minimum wage to the unemployed (CoGTA 2018). By 2013, the CWP had doubled its size and was operating in 154 sites, with 204000 participants (Philip 2013:7).

The CWP may be regarded as an LED initiative, as it is implemented at a local sphere, within local communities in order to fight poverty and unemployment at a local level regardless of unemployed individuals' circumstances. Community Work Programme provides employment to people 'as they are, regardless of their skills, education or personal characteristics' (Webster et al. 2011:4).

From a qualitative study of the perceptions and experiences of CWP participants in Braamfischer, Mathende (2015:26) concluded that they not only gain work opportunities and skills through on-the-job training but also access to a better social network, information on development opportunities and experience in teamwork and social inclusion support, which enhances unity in the communities. From their studies on CWPs in various municipalities in South Africa, Mullagee and Bruce (2015:39), Bruce (2015:33) and Langa (2015:38) all concluded that the CWP does not only provide job opportunities and skills within the communities, but it also enhances unity and serves as an instrument to fight and reduce crime within communities.

The distinctiveness of CWP lies in its innovative solution for unemployment and permanency (Shumba 2017:96). The strength of the CWP is centred in the development and participation of the community. Community Work Programme has been identified as a unique PWP globally, with various stakeholders such as government, non-governmental organisations and community members (Shumba 2017:96).

Most previous studies, such as those conducted by Meth (2011) and Mogagabe (2016), focused on the EPWPs and not the CWPs. Studies that focused on CWPs (Mathende 2015; Mullagee \& Bruce 2015) investigated these programmes' impact on the livelihoods of the participants and not its impact on unemployment. Based on this gap in the literature, there is insufficient evidence on the challenges faced by the CWPs, the type of skills developed within these programmes, and if participants can secure long-term employment once they exit the CWP. Previous research by Mullagee and Bruce (2015) and Mathende (2015) provided no evidence of the programme's success in enabling participants to obtain longterm employment.

Some researchers, such as Andersson and Alexander (2016:175), emphasised that the CWP is one of the most efficient ways to spend public money, as the programme has the capacity to mobilise community resources, improve local economies and forge partnerships within government and public sectors. The authors further elaborated that the CWP has the potential to reduce unemployment, enhance the livelihoods of participants and develop local communities. Trade and Industrial Policy Strategies (TIPS) (2011:15) conducted a qualitative evaluation of the CWP and concluded that community members were pleased with the services received from the CWP participants, such as home-based care services and clean schools:

Communities in Randfontein and uMthwalume declared the positive contribution of CWP to their respective communities. These communities appreciated the home-based care, cleaning of public spaces, and the food gardens offered by the programme. (TIPS 2013:77)

The CWP's contribution to crime reduction and community development was evident in the findings reported by Langa (2015), Bruce (2015) and Mathende (2015). The study by the TIPS (2011) focused more on the benefit of the programme within communities and not the challenges and benefits participants encountered within the programme.

\section{National framework of local economic development 2017-2022}

The conceptual framework used to guide the study is the NFLED 2017-2022, which was implemented to ensure the success of LED. The NFLED focuses on contributing to quality of life by improving social cohesion, human dignity, economic inclusivity and spatial justice at the local level (SALGA 2016:22). The NFLED consists of six strategic pillars, namely building diverse and innovation-driven local economies, developing inclusive economies, developing learning and skilful economies, enterprise development and support, economic governance and infrastructure and strengthening local system of innovation. Strategic pillars 2 and 3 emphasise that one of the crucial roles of the national framework is reinforcing the local government's position in community development, through community service support and skill development programmes. These key thematic areas and concepts formed the analytical framework, which guided the instrument design, data collection and data analysis. 


\section{Research problem and research objective}

The effectiveness of a CWP, in terms of achieving its primary objective of improving the livelihoods of poor people and decreasing the unemployment rate in Erasmus and Soshanguve is not clear because the unemployment rate is increasing. Neither is it known what challenges CWP participants are experiencing and whether they are equipped to start their own businesses or to find permanent employment.

The primary objective is to assess the extent to which the CWP contributes to sustainable job creation in Region 1 of Tshwane Metropolitan Municipality (Erasmus and Soshanguve) and whether these CWP participants have been empowered to secure long-term employment or start their own business.

\section{Research methodology}

Adopting both a descriptive and evaluative research approach and a positivistic philosophy, a cross-sectional quantitative survey was conducted to collect primary data (Saunders, Lewis \& Thornhill 2019) from Region 1 of the Tshwane Metropolitan Municipality communities where the programme is implemented (Erasmus extension 11 and Soshanguve). At the seven CWP sites in Erasmus extension 11 and Soshanguve, 2000 participants, 110 supervisors and one manager are employed (a total of 2111), as follows:

- Food security and security support had about 600 participants. They focus on gardening services and food production. The security support personnel ensure that tools and sites are kept safe.

- Mentorship had about 150 participants. They provide support to youth through the provision of basic skills and encouragement on how to deal with life's challenging situations, such as drugs and peer pressure.

- Support for early childhood development had about 200 participants. They focus on providing basic educational development to children prior to primary education.

- Support to schools had about 200 participants. They ensure that schools are clean and well cared for.

- Community safety had approximately 300 participants, and their main objective is to transform what is commonly known as 'dangerous spots/places' into safe ones, to ensure community members are safe.

- Home-based care and auxiliary care services had an estimated 300 participants and their main objective is to ensure that the elderly and the sick are well taken care of in the community.

- Environmental programmes, with an estimated 250 participants, focus on transforming unoccupied spaces into parks or vegetable gardens.

Owing to the national COVID-19 lockdown implemented in March 2020, all CWP participants and supervisors had not yet returned to the respective sites in October 2020. Probability sampling was not possible. The CWP programme manager, invited all the CWP participants and supervisors to a meeting at the Erasmus site, where strict hygiene regulations were adhered to by allowing only 40 CWP participants inside the hall. As all 2111 employees from Region 1 were invited, and a sample was not drawn, it is the equivalent of a census. The same structured questionnaire in English was used for all to complete. On Day 1, 150 questionnaires were completed owing to the limitation of 40 respondents in the hall at any one time. Respondents who could not read and write, were assisted by the researcher who is fluent in Tswana, the local vernacular. Only those who had not completed the questionnaire, were invited to return either the next day or any day until Friday. On Day 2, 50 questionnaires were completed and on Day 3, only 20 questionnaires were completed. No one arrived on Day 4 and 5. A total of 219 questionnaires (219/2111 is an $11 \%$ response rate) were completed - 190 CWP participants and 29 CWP supervisors.

Some CWP participants did not return after the first day, because there was no reward for completing the questionnaire. Others did not return because they did not see any benefit for themselves in completing the questionnaire. Some elderly participants were discouraged from participating as they do not understand English and would have needed a translator to assist with the completion of the questionnaire.

A structured questionnaire informed by the literature review and refined by the statistician and including a letter of consent was pilot tested with five respondents from a similar programme. No adjustments were required. After ethical clearance was granted by the School of Economics Committee for Ethics at the University of Johannesburg, primary data collection through mostly self-completed questionnaires and some researcher-assisted completed questionnaires commenced. Descriptive statistics were used to analyse the numerical data.

\section{Ethical considerations}

Approval to conduct the study was obtained from the School of Economics Ethics Clearance Committee, University of Johannesburg, reference number: FEFSREC2017082901.

\section{Results and discussions Demographic profile of respondents}

Of the 219 respondents, $87 \%$ are CWP participants, whilst $13 \%$ are supervisors. Nearly two-thirds of this sample (63\%) are females, whilst a third are males (37\%). The gender disparity can be partly explained by the aim of the CWP programme to empower women to reduce high levels of poverty and unemployment amongst women in rural areas. These percentages echo those of Philip (2013:11) whose study of 400 CWP participants from 6 communities in South Africa included 70\% females. Trade and Industrial Policy Strategies (TIPS 2014:21) testified that the unemployment and poverty level amongst women is disproportionally high. 
With regard to age distribution, according to the age classification of Stats SA (2015), 37\% of the respondents are youth (20-35 years), whilst $24 \%$ are from the prime age group (36-45 years), with $21 \%$ in the mature age group (46-55 years) and $18 \%$ in the elderly working age group (56-65 years). The large proportion of youth active in the programme aligns with the unemployment statistics in the country. In the first quarter of 2020, $43.2 \%$ of South African youth were reported to be unemployed (Stats SA 2020:1).

According to CoGTA (2018:18), the CWP not only aims to provide employment but also to support youth development in poor localities.

With regard to level of education, $60 \%$ of the respondents did not have a matric certificate, whilst $40 \%$ had a matric certificate, of which a few had a tertiary diploma or degree. According to the CWP manual (CoGTA 2018:26), the programme provides work at the local level sphere for those over 18 years who are willing and able to work, regardless of gender or level of education.

Mathende (2015:88) emphasised that employment guarantee schemes, such as the CWP, provide work to 'rural people of legal age willing to work'. Owing to the high unemployment rate, it would be challenging for people without a matric qualification to acquire employment in the formal labour market. In summary, most of the respondents were women, under the age of 45 years and without a matric qualification.

\section{Job creation through the community work programme}

To ascertain the CWP's effectiveness in unemployment alleviation in Region 1 of the Tshwane Metropolitan Municipality, respondents' employment status at the time of joining the CWP, length of their unemployment before joining the CWP, by gender; previous and current sector participation in the CWP; tenure in the CWP and the benefits received were determined.

\section{Employment status of respondents at the time of joining the community work programme}

At least $51 \%$ of respondents were working before joining the CWP programme. These respondents explained that they joined the programme, as they believed the programme would improve their livelihoods and equip them with new skills. The CWP is primarily aimed at unemployed or underemployed local people, who are of legal working age, in order to alleviate the level of poverty in poorer communities (Andersson \& Alexander 2016:157). In the study by Mullagee and Bruce (2015:18), most of the CWP respondents were unemployed.

\section{Length of unemployment prior to joining the community work programme}

Of the 108 unemployed prior to joining the CWP, the period of unemployment ranged from 1 to 30 years (Table 1). Half of the respondents had been out of the job market for 5 or more years. Two-thirds (68\%), were unemployed for a period of 1 to 5 years prior to joining the programme, whilst $21 \%$ were unemployed for a period of 6 to 10 years before joining the programme. With the exception of one male respondent, only female respondents had been unemployed between 11 and 30 years before joining the CWP. Outliers of 29 years and 30 years of unemployment were reported by two females, respectively. Whereas $52 \%$ $(72 / 138)$ females were unemployed prior to joining the CWP, fewer males (44\%) $(36 / 81)$ were unemployed. It seems that for some, the CWP was a last resort of possible employment.

\section{Respondents' tenure in the community work programme}

Of the 219 respondents, $58 \%$ had been active in the programme for a period between 1 and 5 years, whilst $30 \%$ for a period between 5 and 10 years (Figure 1). As many as $12 \%$ of the CWP participants had been active in the programme since its inception 11 years ago. Similarly, Mullagee and Bruce (2015:18) found that in Manenberg,

TABLE 1: Respondents' duration of unemployment prior to joining the community work programme.

\begin{tabular}{|c|c|c|c|c|c|}
\hline $\begin{array}{l}\text { Number of } \\
\text { years } \\
\text { unemployed }\end{array}$ & $\begin{array}{l}\text { Females: } \\
\text { Number of } \\
\text { respondents }\end{array}$ & $\begin{array}{c}\text { Males: } \\
\text { Number of } \\
\text { respondents }\end{array}$ & $\begin{array}{l}\text { Total: Female } \\
\text { and males }\end{array}$ & Total: \% & $\underset{\%}{\text { Cumulative }}$ \\
\hline 1 & 6 & 6 & 12 & 11 & 11 \\
\hline 2 & 11 & 6 & 17 & 16 & 27 \\
\hline 3 & 10 & 4 & 14 & 13 & 40 \\
\hline 4 & 8 & 3 & 11 & 10 & 50 \\
\hline 5 & 13 & 6 & 19 & 18 & 68 \\
\hline 6 & 3 & 1 & 4 & 4 & 72 \\
\hline 7 & 2 & 0 & 2 & 2 & 74 \\
\hline 8 & 0 & 1 & 1 & 1 & 75 \\
\hline 9 & 2 & 1 & 3 & 3 & 76 \\
\hline 10 & 7 & 7 & 14 & 13 & 89 \\
\hline 11 & 3 & 0 & 3 & 3 & 92 \\
\hline 12 & 2 & 0 & 2 & 2 & 94 \\
\hline 14 & 1 & 0 & 1 & 1 & 95 \\
\hline 15 & 1 & 0 & 1 & 1 & 96 \\
\hline 17 & 0 & 1 & 1 & 1 & 97 \\
\hline 20 & 1 & 0 & 1 & 1 & 98 \\
\hline 29 & 1 & 0 & 1 & 1 & 99 \\
\hline 30 & 1 & 0 & 1 & 1 & 100 \\
\hline Total & 72 & 36 & 108 & 100 & - \\
\hline
\end{tabular}

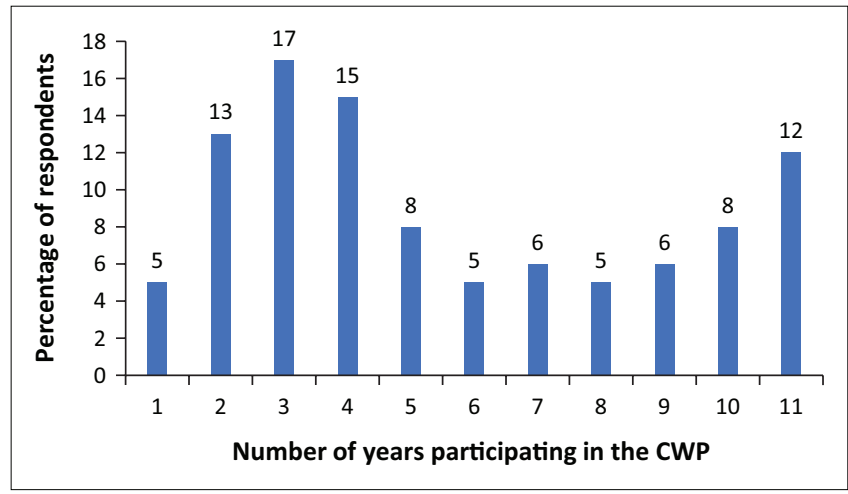

CWP, community work programme.

FIGURE 1: Respondents' number of years participating in the community work programme. 
some CWP participants had joined the programme since its inception 8 years ago. Although the CWP is regarded as a programme that will provide a stable and ongoing income to its participants (Philip 2013:1), it is unclear how long individuals may participate in the programme. The fact that so many CWP respondents had been participating for so many years, raises a question of the CWP's ability to upskill participants to find employment elsewhere.

\section{Previous and current sector participation in the community work programme}

The CWP has four main sectors, namely agriculture, social, environmental and infrastructure, with the social sector having five subsectors (Table 2). Nearly half of the respondents $(48 \%)$ have been involved in more than one sector of the CWP, whilst the other half (52\%) have only participated in one sector since they joined the programme. Participating in more than one sector could contribute to the participant learning different skills and being more empowered.

Respondents were asked to indicate the sector and subsector in which they had previously been employed and their current employment. At the time of data collection, more of the respondents (37\%) participated in the agriculture sector and in the five social sectors (Figure 2).

Previously, the participation in the social sector was higher than that of the environmental and agricultural sectors. The low allocation rate to the infrastructure sector, where participants can learn plumbing, bricklaying, welding and electrical skills, is of concern. These are skills that would enable CWP participants to obtain long-term employment or start their own business. However, the CWP allocation of participants is restricted by the need and capacity in a sector.

The CWP focuses on 'useful work, which is defined as work that contributes positively to the public and improves the standard of living in communities in South Africa' (TIPS 2018:36). The CWP aims to counteract local food scarcity by planting and maintaining food gardens to provide food for the community, the school children and early development centres in Erasmus and Soshanguve (TIPS 2011:1). Most gardens are planted on community land and the school premises.

TABLE 2: Sectors and subsectors for community work programme participation.

\begin{tabular}{ll}
\hline CWP sectors & CWP subsectors \\
\hline Agriculture & Food security and security support \\
Social & $\begin{array}{l}\text { Mentorship } \\
\text { Support to early childhood development centres } \\
\text { Support to schools } \\
\text { Community safety } \\
\text { Home-based care and auxiliary care services }\end{array}$ \\
Environmental & Environmental programmes and recycling \\
Infrastructure & Plumbing, bricklaying, welding and electrical \\
\hline
\end{tabular}

CWP, community work programme.
Similarly, in Braamfischer, through the CWP's vegetable gardens, school children received healthy meals as part of school feeding schemes (Mathende 2015:71). A question was not asked to determine how many of the CWP participants had started their own vegetable gardens and this should be addressed in future research.

\section{Community work programme sectorial participation by gender and qualification}

According to the CWP manager, administrators assign CWP participants to sectors according to the needs of a sector and the participant's attendance register. Although their qualifications are not taken into account, skills acquired after having participated in the programme for some time may be taken into consideration.

Regarding CWP sector participation, for most of the sectors, the percentage participation of males and females is very similar (Table 3). In only two sectors a clear difference is evident: more males (30\%) participate in the 'environmental programmes and recycling' sector compared with females $(20 \%)$, whilst more females $(12 \%)$ participate in the 'support to schools' sector than males (5\%).

Although qualification is not a consideration when assigning participants to sectors, comparing the CWP sector participation of those without and those with a matric certificate, it seems that those without a matric certificate gravitate towards the following three CWP sectors (Table 3):

- Home-based care and auxiliary services (without matric $7 \%$ vs. $2 \%$ with matric).

- Mentorship (without matric $8 \%$ vs. $2 \%$ with matric).

- Support to schools (without matric $14 \%$ vs. $5 \%$ with matric).

Respondents with matric or higher education levels seem to participate more frequently in the following three CWP sectors (Table 3):

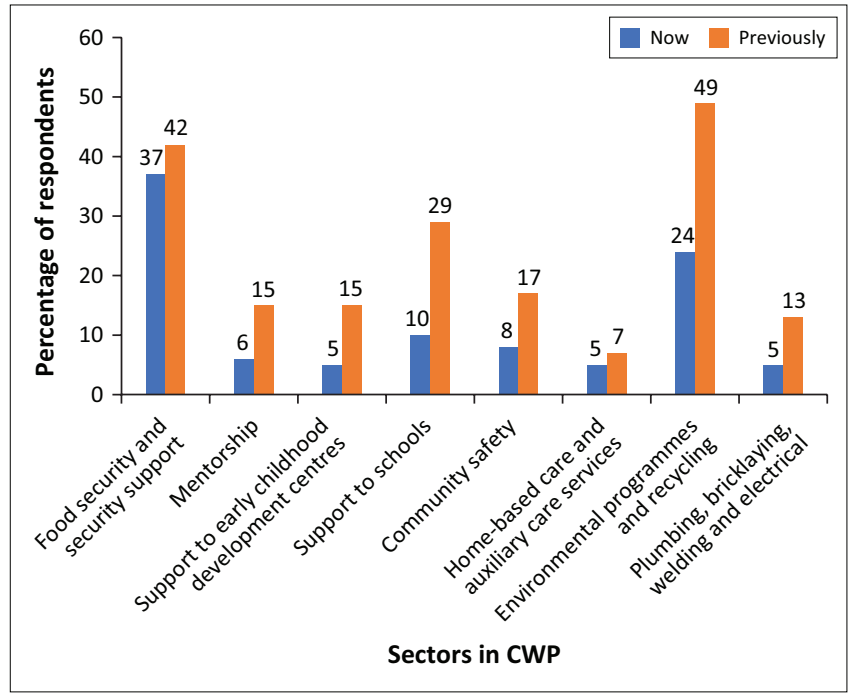

CWP, community work programme.

FIGURE 2: Respondents' employment in community work programme sectors. 
TABLE 3: Respondents' community work programme sectoral participation; by gender and qualification.

\begin{tabular}{|c|c|c|c|c|c|c|}
\hline \multirow[t]{2}{*}{ Sectors in the CWP } & \multicolumn{2}{|c|}{ Gender } & \multicolumn{2}{|c|}{ Educational level } & \multicolumn{2}{|c|}{ Total } \\
\hline & $\begin{array}{c}\text { Male, } n=81 \\
(\%)\end{array}$ & $\begin{array}{c}\text { Female, } n=136 \\
(\%)\end{array}$ & Without matric (\%) & Matric \& higher (\%) & Frequency & $\%$ \\
\hline Social sector - Community safety & 8 & 8 & 8 & 8 & 18 & 8 \\
\hline Social sector - Support to early childhood development centres & 5 & 5 & 5 & 5 & 11 & 5 \\
\hline Environmental sector - Environmental programmes \& recycling & 30 & 20 & 21 & 28 & 53 & 24 \\
\hline Agriculture - Food security \& security support & 36 & 38 & 33 & 42 & 80 & 37 \\
\hline Social sector - Home-based-care and auxiliary care services & 3 & 6 & 7 & 2 & 11 & 5 \\
\hline Social sector - Mentorship & 8 & 6 & 8 & 2 & 13 & 6 \\
\hline Infrastructure sector - Plumbing, bricking, welding and electrical & 5 & 5 & 4 & 8 & 11 & 5 \\
\hline Social sector - Support to schools & 5 & 12 & 14 & 5 & 22 & 10 \\
\hline Total & 100 & 100 & 100 & 100 & 219 & 100 \\
\hline
\end{tabular}

CWP, community work programme.

- Environmental programmes and recycling (with matric $28 \%$ vs. $21 \%$ without matric).

- Food security and security support (with matric $42 \%$ vs. $33 \%$ without matric).

- Plumbing, bricklaying, welding and electrical (with matric $8 \%$ vs. $4 \%$ without matric).

Nevertheless, there seems to be limited opportunities within the infrastructure sector for both education levels, as only $11(5 \%)$ of the total 219 participants were employed to work as plumbers, bricklayers, welders and electricians. However, the allocation of participants to a sector is dependent on and limited by the demand and the size of each sector.

\section{Benefits received from the community work programme}

From a predetermined list of 10 possible benefits, respondents could select multiple options of benefits received whilst participating in the CWP. The list included monthly income, on-the-job training, skill transfer, teamwork, building friendships, easy access to information and improvement in self-confidence from participating in the programme (Table 4). As all 10 options were selected by a range of $166(77 \%)$ to 209 (96\%) respondents, it seems that they benefited to various degrees (Table 4). Whilst it is expected that the majority of participants (96\%) participate in the CWP for financial gain, the CWP contributes to several other benefits, such as skill development as $90 \%$ claim to have learnt 'new skills', with $83 \%$ having received 'on-the-job training' and $81 \%$ having gained 'experience in a specific job'. With regard to finding alternate employment, $76 \%$ reported 'I have heard about job opportunities', whilst 77\% indicated that 'I have access to information to look for a job'.

In addition to income, the CWP supports its participants' social needs, as reflected by quite a high response on learning about teamwork (90\%), stronger self-esteem/confidence $(87 \%)$, making friends (86\%) and unity within the community (86\%). Apart from receiving regular work, the benefits received by the participants are not only short-term, material and quantifiable but also qualitative, social and lasting (Andersson \& Alexander 2016:173).
TABLE 4: Benefits received by respondents from the community work programme.

\begin{tabular}{lcc}
\hline Benefits received & Frequency & $\mathbf{\%}$ \\
\hline I receive monthly income & 209 & 96 \\
I have learned new skills & 196 & 90 \\
I have learned about teamwork & 197 & 90 \\
$\begin{array}{l}\text { I have stronger self-esteem/confidence because I am } \\
\text { working }\end{array}$ & 191 & 87 \\
I have made friends that help me & 194 & 86 \\
There is unity in the community & 189 & 86 \\
I received on-the-job training & 182 & 83 \\
I have gained experience in a specific job & 177 & 81 \\
\hline I have access to information to look for a job & 168 & 77 \\
I have heard about job opportunities & 166 & 76 \\
\hline
\end{tabular}

Mullagee and Bruce (2015:34), in their study of Manenberg, emphasised that the programme enhanced social cohesion and the number of gangs decreased as more people were employed.

Similar results were found in Orange farm, where CWP not only reduced poverty levels but also contributed positively to reducing violence and drug dealing in the community, enhancing the spirit of ubuntu, unity, care and love amongst the community members (Langa 2015:37). The results support the theory of communitarianism, which refers to a relationship rooted in social communities and common understanding (Van Leeuwen 2015:1). From the results, it follows that the CWP increased social cohesion, ubuntu and unity in Erasmus and Soshanguve. According to Vawda et al. (2013:5), 'ubuntu' or communitarian approach can empower the poorest of individuals and is deeply rooted in poor communities. Furthermore, the results provide evidence of growth and development as the respondents gained more than just an employment opportunity and some skills, but have an improved self-esteem.

\section{Contribution of the community work programme in Erasmus and Soshanguve}

On a list of seven possible social contributions of the CWP, using a 4 -point Likert scale ( $1=$ no extent, to $4=$ large extent), respondents indicated the extent to which the CWP contributes socially to Erasmus and Soshanguve. Of the 219 respondents (Table 5), very few responded to the first four of the seven possible social contributions. This lack of response could be an indication of total 
TABLE 5: Respondents' perception of the extent to which community work programme develops Erasmus and Soshanguve.

\begin{tabular}{|c|c|c|c|c|c|c|c|c|c|c|c|}
\hline \multirow[t]{2}{*}{ Social contribution options } & \multicolumn{2}{|c|}{ No extent (1) } & \multicolumn{2}{|c|}{ Small extent (2) } & \multicolumn{2}{|c|}{ Moderate extent (3) } & \multicolumn{2}{|c|}{ Large extent (4) } & \multicolumn{2}{|c|}{ Total } & \multirow[t]{2}{*}{ Mean } \\
\hline & $n$ & $\%$ & $n$ & $\%$ & $n$ & $\%$ & $n$ & $\%$ & $n$ & $\%$ & \\
\hline $\begin{array}{l}\text { Mostly previously unemployed } \\
\text { people are working }\end{array}$ & 1 & 8 & 1 & 8 & 2 & 15 & 9 & 69 & 13 & 100 & 3.46 \\
\hline Streets and schools are clean & 1 & 4 & 0 & 0 & 4 & 15 & 22 & 81 & 27 & 100 & 3.74 \\
\hline $\begin{array}{l}\text { Teenagers receive proper } \\
\text { guidance and mentoring }\end{array}$ & 0 & 0 & 7 & 33 & 7 & 33 & 7 & 33 & 21 & 100 & 3.0 \\
\hline $\begin{array}{l}\text { Elderly and sick people are } \\
\text { taken care off }\end{array}$ & 0 & 0 & 8 & 27 & 8 & 27 & 14 & 46 & 30 & 100 & 3.2 \\
\hline There is safety and less crime & 6 & 8 & 26 & 35 & 32 & 43 & 10 & 14 & 74 & 100 & 2.62 \\
\hline $\begin{array}{l}\text { There is skills transfer within } \\
\text { the community members }\end{array}$ & 1 & 2 & 28 & 51 & 22 & 40 & 4 & 7 & 55 & 100 & 2.50 \\
\hline $\begin{array}{l}\text { There is more unity between } \\
\text { community members }\end{array}$ & 3 & 1 & 27 & 13 & 62 & 29 & 120 & 57 & 212 & 100 & 3.41 \\
\hline
\end{tabular}

TABLE 6: Challenges experienced by the respondents with the community work programme in Erasmus and Soshanguve.

\begin{tabular}{|c|c|c|c|c|c|c|c|c|c|c|c|}
\hline \multirow[t]{3}{*}{ Type of challenge } & \multicolumn{8}{|c|}{ Extent of challenge experienced } & \multirow{2}{*}{\multicolumn{2}{|c|}{ Total }} & \multirow[t]{3}{*}{ Mean score } \\
\hline & \multicolumn{2}{|c|}{ Not a challenge (1) } & \multicolumn{2}{|c|}{ Small challenge (2) } & \multicolumn{2}{|c|}{ Moderate challenge (3) } & \multicolumn{2}{|c|}{ Large challenge (4) } & & & \\
\hline & $n$ & $\%$ & $n$ & $\%$ & $n$ & $\%$ & $n$ & $\%$ & $N$ & $\%$ & \\
\hline Lack of training & 12 & 20 & 20 & 33 & 9 & 15 & 19 & 32 & 60 & 100 & 2.58 \\
\hline Poor working conditions & 27 & 39 & 16 & 23 & 23 & 33 & 3 & 5 & 69 & 100 & 2.02 \\
\hline Non-payment or late payment of wages & 16 & 13 & 26 & 21 & 30 & 24 & 51 & 42 & 123 & 100 & 2.94 \\
\hline No safety and health assistance at work & 44 & 23 & 61 & 31 & 54 & 28 & 35 & 18 & 194 & 100 & 2.41 \\
\hline Other & 11 & 46 & 2 & 8 & 2 & 8 & 9 & 38 & 24 & 100 & 2.37 \\
\hline
\end{tabular}

disagreement with the statements. For example, mostly previously unemployed people are working $(13 / 216=6 \%$ response rate). Streets and schools are clean $(27 / 216=12 \%$ response rate); teenagers receive proper guidance and mentoring $(21 / 216=10 \%$ response rate $)$ and elderly and sick people are taken care of $(30 / 216=14 \%$ response rate $)$. However, the few who responded to these four possible contributions were positive about their contributions to the community.

With regard to 'skills transfer within the community members', the 55 responses fluctuate between 'a small extent' (51\%) and 'a moderate extent' (40\%). Respondents were a little more positive that 'there is safety and less crime', with the 74 responses fluctuating between 'a small extent' (35\%) and 'a moderate extent' (43\%).

However, with regard to the following statement, 'there is more unity between community members', respondents were much more positive; of the 212 who responded, 57\% indicated 'a large extent', with a further $29 \%$ indicating 'a moderate extent ${ }^{\prime}$.

The environmental programme supervisor added that the income received from recycling is utilised to build early development centres, storage rooms and offices in Erasmus and Soshanguve. It follows that the programme is partly self-funded and contributes positively to the community. As a contribution towards social welfare, 'the South African government implemented the CWP to attempt and provide for the livelihoods of impoverished people through the programme that would also assist with developing these communities' (Van der Merwe \& Langa 2019:50). From Table 5, it does not seem as if the participants are convinced that the CWP contributes to the development of the poor communities and in particular not as far as skills are concerned.

\section{Challenges experienced within the community work programme in Erasmus and Soshanguve}

On a 4-point Likert scale respondents from the CWP in Erasmus and Soshanguve indicated the extent to which suggested challenges had been experienced. They had the option to add 'other' challenges (Table 6). The main challenge, with a mean score of 2.94, seems to be nonpayment or late payment of wages. Of the 123 respondents who reported this challenge, $42 \%$ considered it a 'large challenge' whilst $24 \%$ considered it a 'moderate challenge'. Late payment has been a challenge at least since 2011 when Philip (2013:30) found that one of the challenges faced nationwide was delays in payments and the provision of tools and working materials.

The challenge 'no safety and health assistance at work' had the greatest response rate with as many as 194 of the 219 possible respondents commenting. With a mean score of 2.41, it seems that no safety and health assistance at work creates a moderate challenge. Close to a third (32\%) of the 60 respondents stated that 'lack of training' is a large challenge. Only 69 respondents identify 'poor working conditions' as a challenge and with a mean score of 2.02 it tends to be a small challenge.

Of the 24 respondents who selected 'other challenges', such as no work uniform, lack of equipment, machinery and lack of personal protective equipment (PPEs), 9 deemed these as being a large challenge. In Braamfischer, Mathende (2015:87) found that the challenges faced within the CWP related to legal substructures, which provided barriers to work. It follows that the types of challenges may differ from one site to another. 


\section{Employment empowerment within the community work programme}

In this section of the study, the employment empowerment incurred through the CWP in Region 1 of the Tshwane Metropolitan Municipality is explored.

\section{Future employment within the community work programme}

Responding to a question 'Do you think the CWP can employ you for a longer period?', the majority of the respondents (95\% of the 218) believed that the CWP could employ them for a longer period. As some respondents had been active in the programme since its inception, several respondents regarded the CWP as a safety net, and they were confident that they would only exit the programme upon their wish. This view was supported by Philip (2013:9), who stated that the CWP provides 'ongoing access to part-time work for those who need it'.

\section{Job seekers within the community work programme}

To determine whether any of the CWP participants were actively seeking a job, they were asked: 'Are you seeking a job?' Although the majority believed that the CWP could continue to provide them with employment, $84 \%$ claimed to be looking for a job at the time of data collection (Table 7). This could be to secure a higher paying job as the CWP only pays a basic wage. A possible motivation for such job seeking could be the belief that the skills they acquired in this programme are adequate to find another job. The male respondents (90\%) were more actively job seeking compared with the females $(80 \%)$. From a Pearson Chi-Square test (value $=3.568$, $p=0.059)$, the difference is statistically significant at the $10 \%$ level of significance.

\section{Future entrepreneurs in the community work programme}

To determine whether there were prospective future entrepreneurs amongst the respondents, the question 'Are you planning to start your own business?' was asked. The majority of both the male and female respondents (70\%) were planning to start a business (Table 8). The fact that they had gained some skills may contribute to their confidence to start their own business. This high percentage could partly be contributed to the 2016 visit by the Deputy Minister of CoGTA and a representative of small businesses to the CWP in Erasmus to motivate the respondents to register their own business, whilst issuing a few cooperative certificates (CoGTA 2016).

TABLE 7: Respondents who are jobseekers within the community work programme by gender.

\begin{tabular}{|c|c|c|c|c|c|c|}
\hline \multirow[t]{3}{*}{ Gender } & \multicolumn{6}{|c|}{ Seeking for a job (\%) } \\
\hline & \multicolumn{2}{|c|}{ Yes } & \multicolumn{2}{|c|}{ No } & \multicolumn{2}{|c|}{ Total } \\
\hline & $n$ & $\%$ & $n$ & $\%$ & $n$ & $\%$ \\
\hline Female & 111 & 80 & 27 & 20 & 138 & 100 \\
\hline Male & 73 & 90 & 8 & 10 & 81 & 100 \\
\hline Total & 184 & 84 & 35 & 16 & 219 & 100 \\
\hline
\end{tabular}

Pearson $\mathrm{chi}^{2}=3.568 ; p=0.059$
Of the 154 participants who plan to start their own business, $71 \%$ claim to have received support from the CWP to start a business. Apart from considering the skills received as support, some stated that they were motivated to start their own business by the department and programme coordinators. The exact type of support was not queried and should be in future research.

\section{Conclusion}

The research problem is that the CWP's effectiveness, in terms of job creation and improving the livelihoods of poor people in Erasmus and Soshanguve, is not known. The main research question of the study was: 'To what extent does the CWP create jobs within Region 1 of the Tshwane Metropolitan Municipality (Erasmus and Soshanguve)?'

\section{Summary profile of respondents}

Of the 219 respondents, nearly two-thirds were females and one-third males, varying between the ages of 20 and 65 years of age, with $37 \%$ classified as youth. Of the respondents, the majority $(60 \%)$ had no matric, whilst $40 \%$ had a matric certificate, including a few with tertiary qualifications. The sample consisted mostly (87\%) of CWP participants with $13 \%$ supervisors.

\section{The community work programme as a job creator for years to come}

About half (51\%) of the respondents had been employed prior to joining the CWP but left their employment to join the programme - the reasons were not determined. However, it can be assumed that it was more lucrative to be part of the CWP. For the other half of the respondents, the years of unemployment prior to joining the CWP, ranged between 1 and 30 years, with half being unemployed for 5 years or more. Half the respondents have been CWP participants between 5 and 11 years, with $12 \%$ being involved since its inception 11 years ago. It follows that in particular for the previously unemployed CWP participants, the CWP is a job creator and for some the CWP provides long-term employment. There does not seem to be an exit strategy.

The CWP has four main sectors, and some of these have subsectors, resulting in a total of eight sectors and/or subsectors in which the respondents participated. They are assigned to a specific sector according to the needs of that sector. Only about half of the respondents (48\%) have been involved in more than one CWP sector, contributing to the participant learning different skills and being more

TABLE 8: Prospective future entrepreneurs amongst community work programme participants (\%); by gender.

\begin{tabular}{|c|c|c|c|c|c|c|}
\hline \multirow[t]{3}{*}{ Gender } & \multicolumn{6}{|c|}{ Planning to start own business (\%) } \\
\hline & \multicolumn{2}{|c|}{ Yes } & \multicolumn{2}{|c|}{ No } & \multicolumn{2}{|c|}{ Total } \\
\hline & $n$ & $\%$ & $n$ & $\%$ & $n$ & $\%$ \\
\hline Female & 97 & 70 & 41 & 30 & 138 & 100 \\
\hline Male & 57 & 70 & 24 & 30 & 81 & 100 \\
\hline Total & 154 & 70 & 65 & 30 & 219 & 100 \\
\hline
\end{tabular}


empowered. Very few CWP participants are allocated to the infrastructure sector, where they can learn plumbing, bricklaying, welding and electrical skills - this is of concern. However, a larger percentage is allocated to the agriculture sector where they can learn gardening skills, which they can use to provide in their own food security. Whether the CWP participants establish their own gardens was not determined and it should be studied in future research.

\section{Challenges experienced by participants of the community work programme}

From a predetermined list of challenges, the main challenge that emerged is 'non-payment or late payment of wages'. Considering that these are low-wage earners, such late payments would have dire effects on the household survival. Another challenge is the 'lack of safety and health assistance at work'. Some respondents considered the 'lack of training' as a challenge.

Although the CWP is providing job opportunities to those in need, the respondents experienced challenges, which can only be solved by the Department of CoGTA, such as late payment, no uniforms and lack of equipment. Although challenges may vary from one site to another, it is evident that the expansion of the CWP may have created administrative challenges for the government, as Philip (2013:30) also reported late payment as one of the challenges participants faced in the past.

In spite of these challenges, they all benefited to various degrees as indicated on a list of 10 benefits, with the major benefit being financial gain. Other benefits included learning a new skill, receiving 'on-the-job training' and gaining 'experience in a specific job'. However, in spite of gaining some training and skills many participants are not exiting the CWP. With regard to the community, it seems there is more unity in the community as a result of the CWP.

\section{Empowered for permanent employment or starting one's own business}

The objective was to determine whether CWP participants in Region 1 of the Tshwane Metropolitan Municipality had been empowered to secure long-term employment or start their own business. The majority of respondents $(84 \%)$ perceived that they had been empowered by the programme and were looking for a job. As many as 70\% intended to start their own business and of these, $71 \%$ believed that they received enough support from the programme to do so. In spite of these perceptions and intentions, two-thirds $(65 \%)$ of the respondents have been part of the CWP from 4 to 11 years. It seems that the CWP is regarded rather as a social safety net than a labour market contributor.

Although participants might be looking for a better job, if the skills they learntare inadequate to securelong-term employment in a formal market, they might participate in the programme for a longer term. This argument was supported by Adetiba and Qwabe (2020:167), as they emphasised unemployed workers in South Africa have a high probability of remaining unemployed owing to the mismatch of skills and education in the labour market, regardless of efforts in job searching.

\section{Recommendations}

In 2020, the CWP employed over 2000 participants in Erasmus and Soshanguve. Apart from avoiding late payments, the CWP should consider developing exit strategies to systematically empower participants to eventually exit from the programme into a permanent position. Training and mentoring those who want to start a business would align the CWP with Pillar 4 of the NFLED by focusing on entrepreneurship development and support.

Future research should analyse the level of satisfaction with the skills transfer in the CWP in Region 1 of the Tshwane Metropolitan Municipality.

\section{Acknowledgements}

The authors would like to acknowledge the CWP Manager in Region 1 of the Tshwane Metropolitan Municipality, for the assistance provided during the data collection process and providing additional information.

\section{Competing interests}

The authors declare that they have no financial or personal relationships that may have inappropriately influenced them in writing this article.

\section{Authors' contributions}

K.C. K. initiated and conceptualised the project, collected and analysed data and wrote the first report. E.S. critically supervised each stage of the entire research process and wrote and revised the draft manuscripts. M.V., as cosupervisor was actively involved in all stages of the research process and reviewed the manuscript.

\section{Funding information}

The research received no funding from public, commercial or the not-for-profit sector.

\section{Data availability}

The raw data are available from K.C. Kobedi.

\section{Disclaimer}

The views and opinions expressed in this article are those of the authors and do not necessarily reflect the official policy or position of any affiliated agency of the authors.

\section{References}

Adetiba, T.C. \& Qwabe, N.T., 2020, 'The wave of unemployment amongst South African youths: Belonging to a political organisation as a way of escape', Journal of Social Science and Humanities 17(5), 164-179. 
Altman, M. \& Hemson, D., 2007, 'The role of expanded public works programmes in halving unemployment', in Human sciences research council, pp. 1-20, viewed 01 February 2021, from http://repository.hsrc.ac.za/bitstream/handle/20.500. $11910 / 5819 / 4852$ Altman_Roleofexpandedpublicworks.pdf?sequence $=1$.

Andersson, G. \& Alexander, P., 2016, 'The community work programme: Potentials and problems', Transformational Journa/91(1), 157-177. https://doi.org/10.1080/ 13668803.2016.1122710

Baur, P. \& Venter, M., 2019, 'An analysis of a local economic development strategy in the arts and culture sector of the expanded public works programme within South Africa', Journal of Public Administration 54(4.1), 606-628.

Bruce, D., 2015, 'Preventing crime and violence through work and wages the impact of the community work programme', South African Crime Quarterly Number 52(3), 26-37. https://doi.org/10.4314/sacq.v52i1.3

City of Tshwane, 2019, Municipality regions, Pretoria, viewed 13 May 2020, from http://www.tshwane.gov.za/sites/regions/Pages/Region-1.aspx.

Conway, T., De Haan, A. \& Norton, A., 2000, Social protection: New directions of donor agencies, Department for International Development, Social Development, London, viewed 01 February 2021, from https://cdn.odi.org/media/ documents/2233.pdf.

Cook, N., 2019, South Africa: Current issues, economy, and U.S. relations, p. 20 Congressional Research Service Report, Congressional Research Service,
Washington DC, viewed 20 June 2020, from https://crsreports.congress.gov/ Washington DC, viewed
product/pdf/R/R45687

Del Nnino, C., Subbarao, K. \& Milazzo, A., 2009, 'How to make public works work: A review of the experiences', World Bank, viewed 01 July 2020, from https:// openknowledge.worldbank.org/bitstream/handle/10986/11718/567510BRIOBox openknowledge.worldbank.org/bitstream/handle/10986/11
31LIC10SSNPrimerNote31.pdf? sequence=1\&isAllowed $=y$.

Department of Cooperative Governance and Traditional Affairs (COGTA), 1998, South Africa: The White Paper on Local Government (1998), viewed 20 June 2020, from https://www.cogta.gov.za/cgta_2016/wp-content/uploads/2016/06/whitepaperon-loca-gov.pdf.

Department of Cooperative Governance and Traditional Affairs (CoGTA), 2015, Building Safer Communities through the Community Work Programme, CoGTA Pretoria.

Department of Cooperative Governance and Traditional Affairs (CoGTA), 2016, CWP online report, viewed 13 May 2020, from http://www.dta.gov.za/cwp/?p=231.

Department of Cooperative Governance and Traditional Affairs (CoGTA), 2017 Building safer communities through the community work programme, CWP manual, viewed 11 February 2021, from https://www.saferspaces.org.za/ maploads/files/Building-Safer-Communities-through-CWP-SHE1.pdf.

Department of Cooperative Governance and Traditional Affairs (CoGTA), 2018, National framework for local economic development 2018-2028, viewed 10 February 2021, from https://www.cogta.gov.za/led/?page id $=4$.

Department of Cooperative Governance and Traditional Affairs (CoGTA), 2019a, Annual report 2018, Pretoria, viewed 19 April 2020, from https://www.cogta.gov.
za/cgta 2016/wp-content/uploads/2018/11/CoGTA-2019-Annual-ReportApproved-1-compressed-1.pdf.

Department of Cooperative Governance and Traditional Affairs (CoGTA), 2019b Community work programme (CWP), viewed 11 February 2021, from https:// www.cogta.gov.za/index.php/community-work-programme/

Department of Cooperative Governance and Traditional Affairs (CoGTA), 2019c, Expanded public works programme (EPWP), (2019), p. 20, viewed 10 February 2021, from https://www.kzncogta.gov.za/wp-content/uploads/2017/09/EPWPand-CWP-Evaluation-March-2019.pdf.

Department of Cooperative Governance and Traditional Affairs (CoGTA), 2020, National framework for local economic development: Creating innovation-driven
local economies 2018-2028, viewed 30 October 2021, from https://www.cogta. local economies 2018-
gov.za/led/?page_id=4.

Department of Economic Development, 2011, Economic development Department Annual Report 2010/2011, pp. 2-6, viewed 10 February 2021, from https://www.
gov.za/sites/default/files/gcis_document/201409/edd-annual-report-20102011. pov.

Govender, D., Sithebe, P. \& Raiman, T., 2019, The empowerment of locals through the road transportation sector, viewed 01 February 2021, from http://docplayer net/146647828-The-empowerment-of-locals-through-the-road-transportationsector.html.

Kahika, G. \& Karyeija, G.K., 2017, 'Institutional roles and the implementation of local economic development, Kasese District, Uganda', Africa's Public Service Delivery and Performance Review 5(1), 2. https://doi.org/10.4102/apsdpr.v5i1.159

Langa, M., 2015, The impact of the community work programme on violence in Orange Farm, pp. 40-43, Centre for the Study of Violence and Reconciliation (CSVR), Johannesburg.

Langa, M. \& Von Holdt, H., 2011, 'Bokfontein: The Nations are amazed', New South Africa Review, vol. 2, pp. 258-275, Wits University Press, Johannesburg.

Mabusela, T., 2019, Exploring the lived experiences of trainees on the extended public works programme: The Tshwane leadership foundation case, p. 119, University of Pretoria, Pretoria.

Mashinini, I.N., 2018, 'Factors influencing the implementation of local economic development policy in Gert Sibanda District Municipality, South Africa', Student dissertation, University of the Witwatersrand, p. 19.

Mathende, T.L., 2015, 'Perception and experience about the community work programme: A case study of Braamfischer, City of Johannesburg', Master's dissertation, University of Johannesburg, pp. 18-26.

McCord, A., 2005, 'A critical evaluation of training within the South African national public works programme', Journal of Vocational Education and Training 57(4), 563-586. https://doi.org/10.1080/13636820500200302
McCord, A., 2008, 'Recognising heterogeneity: A proposed typology for public works programmes', in A South African Labour and Development Research Unit working paper, issue. 26, p. 1, University of Cape Town, Cape Town.

McCord, A., 2013, 'Public works and resilient food systems', in Federal ministry for economic cooperation and development, p. 1, Research Report. ODI, London.

McCord, A., 2017, The role of public works in addressing poverty: Lessons from recent developments in public works programming, pp. 140-160, Practical Action Publishing Ltd., Warwickshire.

Meth, C., 2011, 'Employer of Last Resort? South Africa's expanded public works programme (EPWP)', in Southern Africa Labour and Development Research Unit, Issue. 58, p. 17, University of Cape Town, Cape Town.

Meyer, D.F., 2014, 'Local economic development (LED), challenges and solutions: The case of the Northern Free State Region, South Africa', Mediterranean Journal of Social Sciences 5(16), 624. https://doi.org/10.5901/mjss.2014.v5n16p624

Mkhatshwa-Ngwenya, E.N.M., 2016, 'Implementation of the expanded public works programme (EPWP) in South Africa (2004-2014)', Master's dissertation, University of South Africa.

Moeti, L., 2013, 'Towards the effective implementation of the public works programme in South African municipalities: A case study of the City of Tshwane Metropolitan Municipality', Master's dissertation, University of South Africa.

Mogagabe, C., 2016, 'Implementation and outcomes of the expanded public works programme (EPWP) in Mabopane', Master's dissertation, Faculty of Commerce, Law, and Management, University of the Witwatersrand.

Mullagee, F. \& Bruce, D., 2015, Building a good Nation in Manenberg: A case study of the Manenberg community work programme, International Development Research Centre, Western Cape.

National Planning Commission, 2013, The national developmental plan, viewed 23 June 2020, from https://www.gov.za/issues/national-development-plan-2030.

Parenzee, P. \& Budlender, D., 2016, Early childhood care and the EPWP: What is the value and implications for poor women and their families?, p. 4, Heinrich Böll Foundation, Cape Town.

Philip, K., 2013, The community work programme: Building a society that works, Employment Sector, Employment Working Paper No. 149.

Puwana, Z., 2015, The community work programme in Grabouw, p. 20, Centre for the Study of Violence and Reconciliation (CSVR), viewed 01 February 2020, from https://idl-bnc-idrc.dspacedirect.org/bitstream/handle/10625/55269/IDL55269. pdf? sequence=1\&isAllowed $=y$.

Republic of South Africa, 2000, Local Government: Municipal Systems Act, no 32 of 2000, viewed 23 June 2020, from https://www.gov.za/sites/default/files/gcis document/201409/a32-000.pdf.

Rogerson, C.M., 2010, 'Local economic development in South Africa: Strategic challenges', Development Southern Africa 27(4), 481-495. https://doi.org/10.108 0/0376835X.2010.508580

Rogerson, C.M., 2014, Reframing place-based economic development in South Africa: The example of local economic development, pp. 204-215, Bulletin of Geography, Socio-economic Series No. 24

Saunders, M.N.K., Lewis, P. \& Thornhill, A., 2019, Research methods for business students, 8th edn., pp. 4-216, Pearson Publication, New York, NY.

Shumba, R., 2017, 'South Africa's community work programme as social entrepreneurship: A sociological perspective', South African Review of Sociology 48(4), 82-100. https://doi.org/10.1080/21528586.2018.1438919

South African Local Government Association (SALGA), 2016, Strategic framework 2017-2022, pp. 8-22, SALGA, Pretoria.

Statistics South Africa (Stats SA), 2015, Millennium development goals: Country report, Pretoria, viewed 01 February 2021, from http://www.statssa.gov.za/MDG/ MDG_Country\%20Report_Final30Sep2015.pdf.

Statistics South Africa (Stats SA), 2020, Quarterly labour force survey, viewed 10 February 2021, from https://www.statssa.gov.za/publications/P0211/ P02111stQuarter2020.pdf.

Statistics South Africa (Stats SA), 2021, Quarterly labour force survey, Pretoria, viewed 10 February 2021, from http://www.statssa.gov.za/publications/P0211/ Media\%20release\%20QLFS\%20Q1\%202021.pdf.

Trade and Industrial Policy Strategies (TIPS), 2011, A qualitative evaluation of the community work programme - Umthwalume CWP by Thutong training and development, viewed 02 August 2021, from https://www.tips.org.za/researchdevelopment, viewed 02 August 2021, from https://www.tips.org.za/research-
archive/inequality-and-economic-inclusion/community-work-programme/ archive/inequality-and-economic-inclusion/community-work-programme/
item/2510-a-qualitative-evaluation-of-the-community-work-programmeitem/2510-a-qualitative-evaluation-of-the-community-work-pro
umthwalume-cwp-october-2011-by-thutong-training-and-development.

Trade and Industrial Policy Strategies (TIPS), 2013, The South African community capability study: The community work programme, viewed 11 February 2021, from http://www.tips.org.za/files/u72/cdi_community_capability_study_2013.pdf.

Trade and Industrial Policy Strategies (TIPS), 2014, Community work programmes, viewed 01 February 2021, from https://www.tips.org.za/projects/past-
projects/inequality-and-economic-inclusion/item/1490-community-workprojects/ine
programme.

Trade and Industrial Policy Strategies (TIPS), 2018, Community work programme: Background materials, viewed 02 August 2021, from https://www.tips.org.za/ research-archive/inequality-and-economic-inclusion/community-workprogramme.

Van Der Merwe, H. \& Langa, M., 2019, 'South Africa's community work programme: Local peacebuilding innovation within a National Developmental Architecture', Journal of Peacebuilding and Development 14(1), 49-62. https://doi. org/10.1177/1542316619832681 
Van Leeuwen, B., 2015, Communitarianism: The International encyclopaedia of political communication, 1st edn., John Wiley, New York, NY.

Vawda, S., Prinsloo, M., Mostert, A. \& Mazibuko, N., 2013, The community work programme, pp. 5-53, Trade and Industrial Policy Strategies (TIPS), Pretoria.

Venter, M., 2014, 'From the lip-service to service delivery in local economic development: Guidelines to set up an agency for action', Journal of Economic and Financial Sciences 3(7), 721-736. https://doi.org/10.4102/jef.v7i3.235
Webster, E., Cock, J., Fakier, K., Masondo, T., Langa, M. \& Von Holdt, K., 2011, The socio-economic impact of the community work programme as a potential Development by the Society, Work and Development Institute (SWOP).

Zulu, N., Nyawo, J. \& Mashau, P., 2017, 'The effectiveness of the expanded public works program in promoting local economic development: A case study of Zibambele Project, eThekwini Municipality', Journal of Economics and Behavioral Studies 9(3), 60-72. https://doi.org/10.22610/jebs.v9i3(J).1746 